\title{
Eko Otellerden Hizmet Satın Alımında Kuşaklar Arası Farklılaşmalar Üzerine Bir Çalışma
}

Pınar BAŞGÖZE, Department of Business Administration, Faculty of Economics and Administrative Sciences, Hacettepe University, Turkey; e-mail: pinaran@hacettepe.edu.tr

Nalan Aslıhan BAYAR, Department of Business Administration, Faculty of Economics and Administrative Sciences, Hacettepe University, Turkey; e-mail: aslihanbayar@hotmail.com

\section{A Study Based on the Generation Differentiations Concerning Service Purchase Intentions for Eco-Hotels}

\begin{abstract}
The study aims to examine the generation differentiations concerning service purchase intentions for eco-hotels. The hypotheses of the study have been designed within the framework of this objective. In order to test the hypotheses and the query questions the questionnaire method was used as the main data collection technique. The sample group of the study consists of 427 people covering 219 X generation participants and 208 Y generation participants. Variance analysis (ANOVA) has been used in order to identify the relationship between the variables of the model. The conclusions reflect that X generation's eco-hotel service purchase intentions are higher than that of Y generation's.

Keywords : $\quad$ Eco Hotel, X Generation, Y Generation.

JEL Classification Codes : $\quad$ M100, M140.

\section{$\ddot{\mathbf{O z}}$}

Çalışmanın amacı, tüketicinin eko otellerden hizmet satın alma eğiliminde kuşak farklılaşmalarının incelenmesidir. Bu amaç doğrultusunda, çalışmanın hipotezlerinin test edilebilmesi için birincil veri toplama yöntemlerinden olan anket yöntemi uygulanmıştır. Araştırmanın örneklemini, X kuşağı (1965-1979 doğumlu olanlar) ve Y kuşağı (1980-1999 doğumlu olanlar) oluşturmaktadır. X kuşağını temsil eden 219 katılımcı ve Y kuşağını temsil eden 208 katılımcıdan oluşan ve toplamda 427 kişilik bir örneklem ile çalışmanın analizi yapılmıştır. Modelde yer alan ilişkinin incelenmesi adına varyans analizi (ANOVA) yapılmıştır. Sonuç olarak X ve Y kuşakları eko otellerden hizmet satın alma eğiliminde farklılaşmış ve X kuşağı içerisinde yer alan katılımcıların eko otellerden hizmet satın alma olasılıklarının daha yüksek olduğu saptanmıştır.
\end{abstract}

Anahtar Sözcükler $\quad$ : $\quad$ Eko Otel, X Kuşağı, Y Kuşağı. 


\section{Giriş}

Eko oteller su ve enerji tasarrufu sağlayan, katı atıkları azaltan, geri dönüşüm ve yeniden kullanım programları uygulayan, sürdürülebilir çevre düzenlemeleri ve ekonomik çözümler geliştiren otellerdir (Güneş, 2011). Çevre üzerinde koruma ve kullanma ilkesinin gözetilmesi ve buna uyulması sürdürülebilirlik açısından gereklidir (Çetin, 2001). Turizm sektörü, genellikle doğal dengenin çok duyarlı olduğu yerlerde gelişmekte ve dikkat edilmediği takdirde, bu doğal denge kolaylıkla bozulabilmektedir (Kızılırmak, 2011). Günümüzde birçok otel, turizm ve çevre ilişkisinin ortaya çıkardığı sorunlara bağlı olarak çevreye verdikleri zararı en aza indirebilmek ve turizmden daha fazla pay alabilmek için çevre dostu uygulamalara geçmek zorunda kalmışlardır (Manaktola \& Jauhari, 2007; Dief \& Font, 2010). "Çevreye duyarlı" davranan kuruluşların etkisiyle ve "çevre dostu" kavramının giderek önemsenmesiyle, eko otel tercih eden sorumlu turist sayısında artış gözlemlenmektedir. Yapılan araştırmalar, günlük hayatlarında çevre dostu davranışlar konusunda olumlu tutumları olan tüketicilerin, konaklama işletmelerinin çevre dostu yönetimlerini de olumlu karşıladığını göstermektedir. Bu bağlamda, tüketicilerin eko otellerden hizmet satın alma eğilimlerinin yüksek olacağı, bu tarz otelleri başkalarına tavsiye edebilecekleri ve bunun için daha fazla maliyete katlanabilecekleri tespit edilmiştir (Han vd. 2009, 2011).

Bunlara ek olarak, tüketicilerin demografik özelliklerinin, tüketim davranışları üzerine önemli etkileri vardır. Özellikle yaş seviyesi, çevre dostu tüketici profilinin belirlenmesinde etkili olabilmektedir (Alnıç̧ı, 2010). Literatürde yer alan farklı çalışmalarda, tüketicilerin yaş gruplarının değişmesi ile tüketicinin davranış ve karar mekanizmasında da farklılıklar olabileceği belirlenmiştir. Dolayısı ile yaş değişkeni ve kuşaklar arası farklılıklar genellikle sosyologların konusu iken, günümüzde iş dünyasının ve pazarlamanın da ilgi odağı haline gelebilmiştir. Her kuşağın sahip olduğu toplumsal değerler ve yetiştirildiği çevre, tüketim alışkanlıklarının bir belirleyicisi olabilmektedir. $\mathrm{Bu}$ nedenledir ki pazarlamacılar, pazara sunacakları yeni ürünlerini; kuşakların farklılıklarını ve buna bağlı tüketim alışkanlıklarını göz önüne alarak şekillendirmektedir (Seçkin, 2000: 101). Böylelikle, tüketicilerin içinde bulundukları kuşak ve bu kuşağa ait özellikler, turizmde satın alma davranışlarını da etkileyebilecektir. Dolayısıyla çalışmanın amacı, tüketicinin eko otellerden hizmet satın alma eğiliminde kuşak farklılaşmalarının incelenmesidir.

\section{Eko Oteller}

Turizm, "insanların yaşadıkları ve çalıştıkları yerler dışındaki alanlara geçici olarak hareketlerini, bu alanlarda konaklamaları esnasında gerçekleştirdikleri aktiviteleri ve kişilerin gereksinimlerini karşılamak için yaratılan olanaklar" şeklinde tanımlanmaktadır (Mathieson \& Wall, 1982: 1). Dolayısıyla konaklama, turizmin olmazsa olmaz unsurlarından biridir. Turizmde sürdürülebilirlik anlayışının gelişmesiyle birlikte "eko otel" 
kavramı da giderek önem kazanmaktadır. Eko oteller literatürde; verimli enerji, su, atık yönetimleri ile doğal kaynakları doğaya saygılı biçimde kullanarak kaliteli hizmet üreten oteller olarak tanımlamaktadır (Cooper I., 1998).

Söz konusu tanımların yanı sıra, Türkiye'de eko otel uygulaması veya tanımlaması Kültür ve Turizm Bakanlığı'nın “Yeşil Yıldız Sertifika Sistemi” ile başlamıştır. Türkiye'de çevre konusundaki duyarlılığın artması ile birlikte dünyadaki uygulamalar ile birlikte söz konusu duyarlılık projesi başlamıștır. Bu kapsamda ilgili kanun (Turizm İşletmesi Belgeli Konaklama Tesislerine Çevreye Duyarlı Konaklama Tesisi Belgesi Verilmesine Dair 2008/3 no'lu Tebliğ) ile belirtilmiş olan kriterlere uyan konaklama tesisleri "Yeşil Yıldız" alabilmekte ve bu doğrultuda müşterilerine hizmet verebilmektedir. Söz konusu kriterler özetle; konaklama işletmelerinin belirlenen çevre ile ilgili politika ve planlarının olması, bu planı uygulayabilecek bir yetkilinin bulunması veya bulunmadığında ilgili konuda uzman bir kişiden yardım alınması, tesis içerisinde çevre bilincinin artırılması ve bu konuda çalışanlara eğitim verilmesi, çevreye duyarlı su kullanımı, işletmede kullanılan tüm tesisat, teçhizat ve donanımların bakımlarının yapılması, enerji tasarruflu ısınma ve soğutma sistemlerinin kullanılması, benzer şekilde tasarruflu elektrik tüketimi, işletmede kullanılan kimyasal maddelerin ve işletmenin neden olduğu atıkların kontrolünün sağlanmasıdır. Türkiye'de özel bir eko otel tanımlaması yapılmadığı için, ilgili bakanlığın özetlenmiş olan kriterlerini tamamlayan oteller eko otel olarak sınıflandırılmaktadır.

Yapılan tanımlar doğrultusunda çalışmada eko oteller, Güneş'in (2011) tanımına benzer şekilde "su ve enerji tasarrufu sağlayan, katı atıkları azaltan, geri dönüşüm ve yeniden kullanım programları uygulayan, sürdürülebilir çevre düzenlemeleri ve ekonomik çözümler geliştiren oteller" olarak tanımlanmaktadır.

\section{Tüketicinin Çevreci Davranışları ve Yaşın Etkisi}

Birçok çalışmada (Anderson \& Cunningham; 1972; Berkowitz \& Lutterman, 1968; Demirbaş, 1999; Keaveney \& Parthasarathy, 2001; Sandahl \& Robertson, 1989; Van Liere \& Dunlap, 1981; Vining \& Ebroe, 1990), tüketicilerin çevreci davranışlarının açıklanmasında; cinsiyet, yaş, eğitim ve gelir gibi demografik faktörlerin etkisi saptanmıştır.

Özellikle yaş seviyesi, tüketicinin çevreci davranışını etkileyen önemli bir faktördür (Alnıaçı, 2010). Yapılan araştırmalarda, tüketicilerin yaş gruplarının değişmesinin, tüketicinin karar verme sürecini ve davranışını etkileyebileceği belirlenmiştir. Bu konuda yeşil tüketici profilini belirlemek için yapılan ilk araştırmalar 1968 yılında başlamıştır. ABD'de “Sosyal Sorumluluk Ölçeği”nin uygulandığ 1 yetişkinlerle yapılan araştırmada (Berkowitz \& Lutterman, 1968) genç tüketicilerin, yaşları ortalamanın üstünde olan tüketicilere göre daha çok sosyal sorumluluk projelerine katıldıkları ortaya konulmuştur. Diğer çalışmalarda (Anderson \& Cunningham, 1972; Van Liere \& Dunalp, 1981)ortalamanın altında yaş seviyesinin, bir başka ifadeyle gençlerin, çevreye karşı daha 
duyarlı olduğu sonucuna varılmıştır. 1990'lı yıllar ve sonrasında yapılan araştırmalarda yaş seviyesinde belirgin değişiklikler olmuştur.1990 yılında Vining ve Ebroe'ın ABD'nin Illinois şehrinde hane halkı ile yapılan “Geri Dönüşüme Gönüllü Katılıp Katılmamaları” ile ilgili çalışmalarda, katılım sağlayan tüketicilerin ortalamanın üstü yaş gurubu olduğu tespit edilmiştir. Diğer bir çalışmada (Sandahl \& Robertson, 1989) çevre dostu tüketicilerin aynı şekilde ortalamanın üstündeki yaş grubu olduğu anlaşılmıştır.

1999 yılından sonra yapılan çalışmalarda (örneğin Jiuan, vd., 2001), yaş ortalaması tekrar değişmiş ve çevre dostu ürünleri çoğunlukla gençlerin tercih ettiği ortaya çıkarılmıştır. Straughan ve Roberts (1999)'un ABD'de bir üniversitede yaptığı çalışmada yeşil pazarlamanın geleceğinin ne olacağı ile ilgili olarak öğrencilerin "Ekolojik Duyarlı Tüketici Davranışları” ölçülmüş ve gençlerin çevreye karşı çok duyarlı oldukları tespit edilmiştir.

Türkiye'de yapılan bir çalışmada; tüketicilerin sosyo-demografik özellikleri ile çevre dostu ürün satın alma davranışları arasındaki ilişkiler ölçümlenmeye çalışılmıştır. Çalışmanın sonuçlarına göre, genç yaştaki tüketicilerin, daha ileri yaştaki tüketicilere oranla daha fazla çevre dostu ürün satın alma eğiliminde oldukları görülmüştür (Çabuk vd., 2008). Mersin'de yapılan bir araştırmanın sonuçlarına göre, daha çok genç yaştaki tüketicilerin çevre bilinçli tüketiciler olduğu tespit edilmiştir (Ay \& Ecevit, 2005). Bir başka çalışmada, çevreci yönelim ve çevre dostu davranış niyeti arasında pozitif bir ilişki saptanmış, aynı çalışmada genç tüketicilerin çevre konusunda daha duyarlı olduğuna ilişkin bulgular desteklenmiştir (Alnıaçık, 2010). Eskişehir'de tüketicilerin çevresel sorumlulukları üzerine yapılan bir araştırmada ise, 26-35 yaş aralığında yer alan tüketicilerin, diğer yaş gruplarına göre çevreci ürünleri daha fazla tercih edebildikleri saptanmıştır (Kükrer, 2012). Bununla birlikte, Kuzey Kıbrıs Türk Cumhuriyetin'de 17 yaş üstü tüketicileri temsil eden bir örneklem ile yapılan çalışmada; çevre bilinci yüksek olan tüketicilerin 40 yaş üstü olduğu anlaşılmıştır (Yeşilada, 2009).

Çevreci davranışlar üzerine yapılan çalışmaların yanı sıra, yaş faktörünün eko otel tercihi üzerine etkileri inceleyen çalışmalara da rastlanılmaktadır. Örneğin Han vd. (2009, 2011), geleneksel otel müşterileri üzerine yaptıkları incelemede, genç yaştaki müşterilerin otel yönetiminin çevreye duyarlı yaklaşımlarını desteklediği ve söz konusu müşteri profilinin eko otel hizmeti satın alma eğiliminin yüksek olabildiği sonucuna varmışlardır. Noor ve Kumar (2014) yaptıkları bir araştırmada; 26-40 yaş arasında yer alan turistlerin, çevre dostu davranış eğilimlerinin yüksek olabileceği ve aynı doğrultuda yeşil otel hizmeti satın alma eğilimlerinin de yüksek olabileceği tespit edilmiştir. Millar ve Baloğlu'nun (2008) çalışmasında da benzer bulgular elde edilmiş ve genç müşterilerin (30-59) daha ileri yaştaki müşterilere (60 yaş ve üstü) oranla daha fazla çevreci otellerde konaklama eğilimi gösterebilecekleri saptanmıştır.

Ancak, her ne kadar yaşın, eko otel hizmeti satın alma eğilimi üzerine etkileri ölçülse de, yazarların ulaşabildiği kadarı ile literatürde eko otel hizmet satın alma eğiliminin 
kuşak sınıflandırmasına göre bir farklılık gösterip göstermediği üzerinde durulmamıştır. Bununla beraber günümüzde hızla gelişen teknoloji ile birlikte ekonomik, toplumsal, kültürel, çevresel ve psikolojik değişimler kuşaklar üzerinde farklı etkiler yaratmaktadır. Her kuşağın sahip olduğu toplumsal değerler ve tüketim alışkanlıkları, yetişme çağlarında onu çevreleyen ortam ve değerlerin etkisiyle çeşitli düşünce ve davranış kalıpları ortaya çıkarabilmektedir. Çok sayıda pazarlama firması; kuşakların özellikleri, tüketim alışkanlıkları ve satın alma eğilimlerinden faydalanarak stratejilerini bu doğrultuda oluşturmaktadır. Dolaysıyla, eko otel hizmet satın alma eğiliminin kuşak sınıflandırmasına göre bir farklılık gösterip göstermediği de merak konusu olabilecektir. Bu nedenle, bir sonraki bölümde kuşak tanımları ve sınıflandırmalar incelenecektir.

\section{Kuşak Olgusu ve Kuşaklar Arası Eko Otel Hizmetlerini Satın Alma Davranışı}

Türk Dil Kurumu "Kuşak" kelimesini "Yaklaşık olarak aynı yıllarda doğmuş, aynı çağın şartlarını, dolayısıyla birbirine benzer sıkıntıları, kaderleri paylaşmış, benzer ödevlerle yükümlü olmuş kişilerin topluluğu" olarak tanımlamıştır (<tdk.gov.tr>). Yıllar boyunca kuşaklar arası farklılıklar sosyologların konusu iken günümüzde iş dünyasının ve pazarlamanın da ilgi odağı haline gelmiştir. Her kuşağın sahip olduğu toplumsal değerler, yetiştirildiği çevre kişinin tüketim alışkanlıklarını belirlemektedir. Pazarlamacılar, piyasaya yeni çıkaracakları ürünlerini; kuşakların farklı tüketim alışkanlıklarını göz önüne alarak şekillendirmektedir (Seçkin, 2000: 101).

Geçmişten günümüze kadar her yeni nesil bir önceki nesle göre gelişmekte ve teknolojik olarak daha ileri gitmektedir. $\mathrm{Bu}$ gelişim de kuşaklar arası farklılıkları yaratmaktadır. Yirminci yüzyılda teknolojinin hızlı gelişmesiyle birlikte kuşaklar arası çatışma daha belirgin hale gelmiştir. "Sosyologlara göre kuşakların doğum yılları aralıkların ve tarihlerin örtüştüğü, sosyal kültürel veya teknolojik olaylar vasıtasıyla farklı özellikler göstermektedir" (Can, 2010).

Gönen'e (2013) göre ${ }^{1}$, kuşak konusunun sosyolojik bir değerlendirme olduğunu belirterek; tanımını şu şekilde yapmıştır; "Belli bir dönemde doğmuş kişilerin gelişim dönemlerinde tecrübe ettikleri soysal, kültürel, politik olaylar ve teknolojik gelişmeler onları diğer kuşaklardan farklılaştırır. Bir kuşak olaylara verdiği tepkiler, kendilerini ifade etme tarzları, hayalleri, istekleri, hedefleri ve motivasyon kaynakları ile diğer kuşaklardan farklılaşabilmektedir" (Akın, 2013).

Kuşaklar doğum tarihine göre; 1925-1945 "sessiz (geleneksel) kuşak", 19461964 “Bebek Patlaması Kuşağı”, 1965-1979 “X kuşağı”, 1980-1999 “Y kuşağı” ile 2000 ve

$1<$ http://www.cumhuriyet.com.tr/haber/diger/426778/Y_kusagini_anlamak_html>, 28.08.2014. 
sonrası "Z kuşağı” şeklinde adlandırılmaktadır. Sessiz (Geleneksel) Kuşak; savaş kuşağı olarak da anılan 1925-1945 yılları arasında iki dünya savaşı arasında doğan kuşaktır. Bu dönemin en önemli olayları II. Dünya Savaşı ve yaşanan ekonomik zorluklardır (Yüzbaşığlu, 2012). "Bebek Patlaması Kuşağı” (1946-1964); savaş yıllarından sonraya denk gelen ve "nüfus patlaması" yıllarında doğan 1 milyar bebeği ifade etmektedir. Yüksek refah düzeyinde büyüyen bir nesildir. Türkiye'de ise ihtilal ve çok partili döneme geçişin yaşandığı yıllardır. Bu kuşakta doğanların sadakat duyguları yüksektir, aynı zamanda kanaatkârdırlar. Örneğin, aynı iş yerinde uzun süre çalışabilirler, ancak teknolojiyi tam benimseyemezler (Mengi, 2009).

X kuşağı (1965-1979); "Bebek Patlaması Kuşağı" içerisine giren bireylerin çocuklarıdır. Dünyada petrol krizi, Türkiye'de siyasi çatışmaların olduğu dönemdir (Mengi, 2009). Yaşanan ekonomik krizlerden ve sosyal zorluklardan etkilenen, kayıp kuşak diye de ifade edilen bir nesildir. Çalışan, birden fazla yerden para kazanan ve işten ayrılmış anne babaların çocuklarıdır. İşsizliği ailelerinde görmeleri nedeni ile işlerine bağlıdırlar ve mecbur olmadıkları sürece işlerini bırakmazlar ya da değiştirmezler. Toplumsal sorunlara karşı duyarlıdırlar. X kuşağı için eğitim çok önemlidir. Teknolojiyle sonradan tanışmış ve zorunlum sebeplerle kullanmaktadırlar (Yüzbaşığlu, 2012). Kadınların iş dünyasına katıldığı ve "daha az çocuk, daha iyi yaşam" felsefesini benimsedikleri dönemdir (Mengi, 2009).

Y kuşağ1 (1980-1999); en önemli özelliği özgürlük ve teknolojidir. Bu kuşakta doğan bireyler çalışmayı sevmemekte, aksine eğlenceyi tercih edebilmektedirler. Otoriteyi sevmemekte, saldırgan davranmaktadırlar. İstekleri çok fazla ve tatminsiz kişiler olmakla birlikte sürdürülebilirlik, etik, sosyal sorumluluk gibi kavramlara önem veren bir profil çizmektedirler (Altuntuğ, 2012). Türkiye'de söz konusu kuşakta yer alan bireyler, 1980 öncesi dönemdeki benzin sıkıntısı ve yağ kuyrukları gibi zorlukları yaşamadıkları için, her şeyi çok hızlı tüketebilmektedirler. Kitlesel olanı değil, kişiye özel olanı sevmektedirler. Bununla birlikte her türlü koşula, değişime kolay uyum sağlamakta ve kendilerini gösterme konusunda çok hevesli davranmaktadırlar. Aynı anda birden çok iş yapabilmektedirler (Mengi, 2009). Y kuşağının temel özellikleri; bilgiye hemen ulaşabilmeleri ve teknolojiyi çok iyi kullanmalarıdır. Bu kuşağın en önemli özelliği, kendilerine çok fazla güvenmeleridir. Teknolojinin doğada yaptığı zararları fark ederek büyümüşlerdir (Yüzbaşığlu, 2012). Y kuşağı Türkiye nüfusunun \%25'ini oluşturmaktadır (Mengi, 2009). Z kuşağı (2000 ve sonrasında doğan kuşak) sınıflandırmanın içerisinde olan ama haklarında henüz çok az şey bilinen kuşaktır (Yüzbaşıŏglu, 2012). Son yıllarda yapılan araştırmalara göre, çevre dostu tüketicileri daha çok 1980 sonrası doğumlu olan ve Y kuşağı olarak sınıflandırılan gençler oluşturmaktadır (Han vd., 2011; Kim vd., 2011).

Literatürde çevreci davranışların kuşaklara göre farklılaşması üzerine yapılan çalışmalar bulunmaktadır. Örneğin Kim vd. (2011)'e göre, Y kuşağının oldukça büyük bir kısmı çevre dostu tüketicilerden oluşmaktadır. Bartolone (2007)'e göre, Y kuşağının \%69'u, alışveriş yaptıkları firmayı seçerken firmanın çevresel ve toplumsal projeleri destekleyip 
desteklemediğine dikkat etmektedir. Bunun yanı sıra Y kuşağının \%47'si çevre dostu ürünler için daha fazla maliyete katlanabilmektedirler.

Y kuşağı diğer kuşaklara göre çevre korumasına daha duyarlıdır ve duyarlı olmasının nedeni doğdukları andan itibaren doğal çevrenin korunması ile ilgili işletmelerin ve hükümetlerin yaptığı yayınlar ve bilgilere maruz kalmalarıdır (Mendeleson \& Polonsky, 1995). Y kuşağının yetişme döneminde, ozon tabakasının delinmesi, doğal kaynakların giderek azalması, küresel ısınma, iklimlerin değişmesi gibi çevreyle ilgili küresel sorunlar ortaya çıkmıştır. Bunun sonucunda, Y kuşağı doğanın korunmasının ne kadar önemli olduğu öğrenerek büyümüştür (Kim, vd., 2011). Y kuşağı aynı zamanda turizmde de bir takım yeşil davranışlara maruz kalmıştır. Örneğin, 1993 yılında "Dünyamızı Koruyalım” kampanyası ile birlikte "Yeşil Oteller Birliği”" anlayışı hakim olmaya başlamıştır. ABD'deki oteller arasında hızla yaygınlaşan kampanyalarla oteller, müşterilerini, çarşafların ve havluların her gün yıkanması sonucu oluşan zararlara karşı bilinçlendirmekte ve her gün değiştirilmesini istemeyecek şekilde seçenekler sunmaktadır (Honey, 2008). Bu nedenle de, doğal hayatın korunması, çevreci ve ekolojik davranışlar en çok Y kuşağı içerisinde yer alan bireylerin yaşamını etkileyebilmektedir.

Yapılan literatür taraması sonucunda yazarların ulaşabildiği kadarı ile, eko otellerden hizmet satın alma eğiliminin kuşaklara göre farklılaşmasını inceleyen tek bir araştırmaya rastlanmıştır. Yalnızca Y kuşağı üzerine yapılan bu çalışmada, söz konusu kuşağın otellerin çevre dostu yönetimleri desteklemek için daha fazla ücret ödeme konusunda istekli olduğu tespit edilmiştir (Kim vd., 2011). Bu çalışmalar 1şığında, X ve Y kuşaklarının eko otellerden hizmet satın alma eğiliminde farklılılaşmalar merak konusu olabilecektir. Bu çerçevede çalışmamızın hipotezi aşağıdaki gibi oluşturulmuştur.

\section{$H 1$ : Eko otellerden hizmet satın alma eğiliminde, $X$ ve $Y$ kuşakları arasında anlamlı bir farklılaşma vardır.}

\section{Metodoloji}

\subsection{Araştırmanın Amacı}

Yapılan araştırmalarda, tüketicinin yaşının tüketim davranışları üzerine etkisi saptanmıştır. Dolaysıyla eko otel satın alma eğiliminde yaşın bir farklılaşmaya neden olabileceği öngörülebilecektir. Çalışmada yaş değişkeni kuşak farklılaşmalarına göre gruplandırılmıştır. Her kuşağın sahip olduğu toplumsal değerler, yetiştirildiği çevre kişinin tüketim alışkanlıklarını belirlemektedir. Buna rağmen eko otel satın alma davranışı söz konusu olduğunda kuşaklar üzerine çalışmaların oldukça az olduğu görülmektedir. 
Dolaysıyla çalışmada, tüketicilerin eko otellerden hizmet satın alma eğilimine ilişkin olarak kuşaklar arasında fark olup olmadığı incelenecektir.

\subsection{Araştırmanın Yöntemi}

Çalışmanın amacına uygun olması ve hipotezlerin test edilebilmesi için birincil veri toplama yöntemlerinden olan anket kullanılmıştır. Ankette katılımcıların seyahatlerinde eko otellerden yararlanma olasılığını ölçmek için "eko otellerden hizmet satın alma eğilimi” ölçeği (Han vd., 2011) kullanılmıştır. Söz konusu ölçüm 5'li likert tipi ölçek ile yapılmış olup 1 "Kesinlikle katılıyorum", 5 ise "Kesinlikle katılmıyorum" anlamı taşımaktadır. Bu soruların yanı sıra, katılımcıların demografik özelliklerinin belirlenmesi amacı ile yaş, cinsiyet, gelir düzeyi ve eğitim durumuna ilişkin 4 ifade yer almaktadır.

\section{3. Örneklem}

Y kuşağı için Hacettepe Üniversitesi İIBF İşletme bölümü öğrencileri, X kuşağ1 için farklı illerde (Ankara, İzmir, İstanbul, Antalya, Edirne, Manisa) yaşayan hane halkı kolayda örneklem yöntemi ile seçilmiş ve örnekleme yüz yüze anket uygulaması yapılmıştır. X kuşağını temsil eden 219 katılımcı ve Y kuşağını temsil eden 208 katılımcıdan oluşan ve toplamda 427 kişilik bir örneklem ile analizler tamamlanmıştır.

Soru kâğıdında araştırma kapsamında verilerin toplandığı katılımcıların yaş, cinsiyet, gelir gibi özelliklerini tanımlamaya yönelik ifadeler yer almaktadır. Bu ifadelerle elde edilen bulguların analizleri yapılarak örneklem hakkında genel bir değerlendirilme yapılması amaçlanmaktadır. Tablo: 1 katılımcıların yaş, cinsiyet, gelir ve eğitim düzeyinden oluşan demografik özellikler gösterilmektedir.

Katılımcıların demografik özelliklerinin gösterildiği Tablo: 1 incelendiğinde; Kuşaklara göre karşılaştırma yapılacağı için X kuşağı (1965-1979 doğumlular) katılımcı sayısı 219 ve Y kuşağı (1980-1999 doğumlular) katılımcı sayısı 208 olarak tespit edilmiştir. Kadın katılımcı \%55 erkek katılımcı \%45 olarak tespit edilmiştir. Buna ilaveten katılımcıların büyük çoğunluğu $(\% 66,7)$ orta gelir grubu düzeyindedir. Ayrıca katılımcıların $(\% 72,6)$ 's1 üniversite mezunudur. 
Tablo: 1

Katılımcılara İlişkin Demografik Özellikler

\begin{tabular}{lrr}
\hline Değişken & Katılımcı Sayısı & Yüzde (\%) \\
\hline Kușak & & \\
\hline X Kuşağı (1965-1979) & 219 & 51.3 \\
Y Kuşağı (1980-1999) & 208 & 48.7 \\
Toplam & 427 & 100 \\
Cinsiyet & & \\
Erkek & 192 & 45 \\
Kadın & 235 & 55 \\
Toplam & 427 & 100 \\
Gelir & & \\
Çok Düşük & 7 & 1,6 \\
Düşük & 34 & 8,0 \\
Orta & 285 & 66,7 \\
Yüksek & 84 & 19,7 \\
Çok Yüksek & 17 & 4,0 \\
Toplam & 427 & 100 \\
Eğitim & & \\
İlköğretim & 14 & 3,3 \\
Lise & 44 & 10,3 \\
Üniversite & 310 & 72,6 \\
Yüksek Lisans & 39 & 9,1 \\
Doktora & 20 & 4,7 \\
Toplam & 427 & 100 \\
\hline & &
\end{tabular}

\section{4. Ölçeklerin Güvenirliği}

Soru kâğıdının güvenirliğini test etmek amacı ile SPSS programında, güvenirlik analizi yapılarak, Cronbach Alpha değerleri incelenmiştir. Eko Otellerden Hizmet Satın Alma Eğilim ölçeğinde değer; 0.916 olarak tespit edilmiştir (Tablo: 2). Hair vd. (2005), ölçek güvenilirliğinin iyi olarak nitelendirilebilmesi için Cronbach's Alpha değerinin 0,70 ve üzeri olması gerektiğini belirtmektedir. Güvenilirliğin 0,60 ve 0,70 arasında olması güvenilirliğin "kabul edilebilir" düzeyde olduğunu ifade etmektedir.

\section{Tablo: 2}

\section{Ölçek Güvenilirliği}

\begin{tabular}{lrr}
\hline Eko Otellerden Hizmet Satın Alma Ĕ̆ilim Ölçĕgi & 0,916 & \\
Seyahatim sırasında eko otelde kalmak isterim & & 0,911 \\
Seyahatim sırasında eko otelde kalmayı planlarım & 0,815 \\
Seyahatim sırasında eko otelde kalmak için çaba sarf ederim & 0,908 \\
\hline
\end{tabular}




\subsection{Hipotez Testi}

Çalışmanın hipotezi; Eko otellerden hizmet satın alma eğiliminde, $\mathrm{X}$ ve $\mathrm{Y}$ kuşaklarına göre tüketiciler arasında farklılık olup olmadığını ölçmek üzere oluşturulmuştur. Çalışmamızda kuşaklararası farklıığın olup olmadığı varyans analizi ile (ANOVA) test edilmiş ve aşağıdaki sonuçlar elde edilmiştir (Tablo: 3 ).

Tablo: 3

Eko Otellerden Hizmet Satın Alma Eğilimi X ve Y Kuşağı Olarak Farklılaşmașı ile İlgili ANOVA Testi Sonuçları

\begin{tabular}{lrrrrc}
\hline Varyansın Kaynağı & Kareler Toplamı & \multicolumn{1}{c}{ sd } & Kareler Ortalamas1 & F & p \\
\hline Gruplar arası & 10,298 & 1 & 10,298 & 9,423 &, $002^{*}$ \\
Gruplar içi & 464,473 & 425 & 1,093 & & \\
Toplam & 474,771 & 426 & & & \\
\hline$* p<0,05$ & & & & &
\end{tabular}

${ }^{*} p<0,05$

ANOVA analizi sonuçlarına göre, $\mathrm{X}$ ve $\mathrm{Y}$ kuşakları, eko otel hizmet satın alma eğiliminde anlamlı olarak farklılaşmaktadır. $(F=9,423, p<0.05)$. Buna göre, $X$ kuşağı (19651979 doğumlu) içinde yer alan tüketicilerin $(M=3,82)$ eko otellerden hizmet satın alma eğilimleri Y kuşağ1 (1980-1999 doğumlu) içerisinde yer alan tüketicilere $(M=3,51)$ göre daha yüksek olabileceği saptanmıştır. Böylece araştırmanın hipotezi desteklenmiştir.

\section{Sonuç}

Çalışmamızda, X (1965-1979 doğumlu) ve Y (1980-1999 doğumlu) kuşakları eko otellerden hizmet satın alma eğiliminde farklılaşmış ve X kuşağının eko otellerde konaklama olasılığının daha yüksek olduğu tespit edilmiştir. Literatürde yer alan çalışmalarda (Bartolone, 2007; Mendeleson \& Polonsky, 1995; Kim, vd., 2011) bu bulgunun aksine, Y kuşağının diğer kuşaklara göre çevrenin koruması konusunda daha duyarlı olduğu savunulmaktadır. Bunun nedeni ise Y kuşağının doğdukları andan itibaren doğal çevrenin korunması ile ilgili işletmelerin ve hükümetlerin yaptığı yayınlar ile bilgilere maruz kalmaları olarak tespit edilmiştir (Mendeleson \& Polonsky, 1995). Ayrıca Y kuşağı yetişirken çevreyle ilgili birçok değişik sorun ortaya çıkmıştır, ozon tabakasının delinmesi, doğal kaynakların giderek azalması, küresel 1sınma, iklimlerin değişmesi gibi küresel problemlerle büyümek zorunda kalmışlardır. Bunun sonucunda, Y kuşağ 1 daha çevreci olarak yetişmiştir (Kim vd., 2011). Literatürdeki bulguların aksine, çalışmanın sonuçlarına göre X kuşağı tüketiciler, Y kuşağına oranla daha fazla eko otellerden hizmet satın alma eğilimi gösterebileceklerdir. Bunun nedeni olarak, $X$ kuşağının belirli bir bilinç düzeyinde olmaları ve gelir düzeylerinin daha yüksek olması şeklinde açıklanabilir. Ayrıca eko oteller (önceki bölümlerde de belirtildiği gibi) geleneksel otellere göre daha yüksek maliyetli olması gelir düzeyi düşük olan öğrenciler (Y kuşağı) tarafindan tercih edilememesinin önemli bir nedeni olabilecektir. 


\section{Araştırmanın Kısıtları}

Her çalışmada olduğu gibi, bu çalışmanın da bazı kısıtları bulunmaktadır. Anket, Y kuşağı olarak sadece Hacettepe Üniversitesi İIBF İşletme bölümü öğrencilerine, X kuşağ1 olarak eğitim ve gelir düzeyi yüksek olan büyük şehirlerde yaşayan kişilere uygulanmıştır. Bu nedenle araştırmanın tüm X kuşağı ve Y kuşağı için genellemesi doğru değildir. Ancak yol gösterici nitelikte olabilecektir.

\section{Kaynakça}

Akın, A. (2013), "Y Kuşağını Anlamak", (09.06.2013), Cumhuriyet Gazetesi, <www.cumhuriyet.com.tr/haber/ 426778>, 09.01.2014.

Alnıaçık, Ü. (2010), “Çevreci Yönelim ve Çevre Dostu Davranış ve Demografik

Özellikler:Üniversite Öğrencileri Üzerinde Bir Araştırma”, Selçuk Üniversitesi, İktisadi ve İdari Bilimler Fakültesi, Sosyal ve Ekonomik Araştırmalar Dergisi, 14(20), 507-532.

Altuntuğ, N. (2012), "Kuşaktan Kuşağa Tüketim Olgusu ve Geleceğin Tüketici Profili”, Organizasyon ve Yönetim Blimleri Dergisi, 4(1), 203-212.

Anderson, T. \& W. Cunningham (1972), “The Socially Conscious Consumer”, Journal of Marketing, 36(3), 23-31.

Ay, C. \& Z. Ecevit (2005), “Çevre Bilinçli Tüketiciler”, Akdeniz İ.I.B.F. Dergisi, 10, 238-263.

Bartolone, G. (2007), “47\% Of Gen Y Would Pay More For Green Brands”, (14.09.2007), Enviromental Leader, <http://www.environmentalleader.com/2007/09/14/47-of-gen-ywould-pay-more-for-green-brands/>, 24.12.2013.

Berkowitz, L. \& K.G. Lutterman (1968), “The Tradional Socially Responsible Personality”, Public Opinion Quarterly, 32, 169-185.

Can, B. (2010), “Gelişen Yeni Nesil İnsan Kaynakları Yönetimini Değiştirecek Mi?”, Progroup, $<$ http://www.progroup.com.tr/tr/makaleler/111-125/gelisen-yeni-nesil-insan-kaynaklariyonetimini-degistirecek-mi/>, 08.01.2014.

Çabuk, S. \& B. Nakiboğlu \& C. Keleş (2008), "Tüketicilerin Yesil (Ürün) Satınalma Davranışlarının Sosya-Demografik Değişkenler Açısından İncelenmesi”, Ç. Ü. Sosyal Bilimler Enstitüsü Dergisi, 17(1), 85-108.

Cooper, I. (1998), "Emerging Issues in Environmental Management”, A.K. (Ed.) içinde: Facility Management: Theory and Practice (111-119), London: Spon Press.

Çetin, İ. (2001), “Turistik Ürün Çeşitlemesinde Eko-Turizmin Yapısal Analizi ve Türkiye'de Geliştirme Stratejileri (Örnek Bir Uygulama)”, Yayınlanmış Yüksek Lisans Tezi, Balıkesir Üniversitesi, Sosyal Bilimler Enstitüsü, Turizm İşletmeciliği ve Otelcilik Ana Bilim Dalı.

Demirbaş, M.A. (1999), "Yeşil Pazarlama Ve Tüketicinin Yeşil Pazarlamaya Yaklaşımı”, Yayınlanmamış Yüksek Lisans Tezi, Gazi Üniversitesi, Sosyal Bilimler Enstitüsü, Ankara.

Dief, M.E. \& X. Font (2010), “The Determinants of Hotels' Marketing Managers' Green Marketing Behaviour", Journal Of Sustainable Tourism, 18(2), 157-174.

Güneş, G. (2011), “Konaklama Sektöründe Çevre Dostu Yönetimin Önemi”, KMÜ Sosyal ve Ekonomik Araştırmalar Dergisi, 13(20), 45-51. 
Hair, J.F. \& B. Black \& B. Babin \& R.E. Anderson \& R.L. Tatham (2005), Multivariate Data Analysis (Sixth Edition b. b.), New Jersey: Prentice Hall.

Han, H. \& L.-T.J. Hsu \& J.-S. Lee (2009), "Empirical Investigation of the Roles of Attitudes toward Green Behaviours, Overall Image, Gender and Age in Hotel Customers Eco-Friendly Decision-making Process", International Journal of Hospitality Management, 28, 519528.

Han, H. \& L.-T.J. Hsu \& J.-S. Lee \& C. Sheu (2011), “Are Lodging Customers Ready To Green? An Examination of Attitudes, Demographics, and Eco-Friendly Intentions", International Journal of Hospitality Management, 30, 345-355.

Honey, M. (2008), Ecoturism And Sustainable Development: Who Owns Paradise, Washinton DC: Island Press.

Jiuan, T. \& J. Wirtz \& K. Jung \& K. Keng (2001), “Singaporeans’ Attitudes Towards Work, Pecuniary Adherence, Materialism,Feminism, Enviromental Conciousness and Media Credibility", Singapore Management Review, 23(1), 59-86.

Keaveney, S.M. \& M. Parthasarathy (2001), "Customer Switching Behavior in Online Services; An Expalatory Study of the Role of Selected Attidunal Behaviraland Demographic Factors", Journal of Academy of Marketing Science, 3, 374-390.

Kızılırmak, İ. (2011), "Dünyada ve Türkiye'deki Turizm İşletmelerinde Çevre Korumaya Yönelik Uygulamalar: Amacı ve Önemi”, Sosyal Bilimler Dergisi, (2), 1-12.

Kim, H. \& H.S. Chang \& J.-W. Lee \& C. Huh (2011), Exploring Gender Differences on Generations $Y$ 's Attitudes Towards Green Practices in A Hotel, <http://scholarworks.umass.edu/cgi/viewcontent.cgi?article=1122vecontext=gradconf_ho spitality>, 23.12.2013.

Kükrer, Ö. (2012), "Tüketicilerin Çevresel Sorumluluklarının Yeşil Reklamlara Yönelik Tutumlarına Etkisi: Eskişehir Örneği”, Journal of Yaşar University, 26(7), 4505-4525.

Manaktola, K. \& V. Jauhari (2007), "Exploring Consumer Attitude and Behaviour Towards Green Practices in the Lodging Industry in India", International Journal of Contemporary Hospitality Management, 19(5), 364-377.

Mathieson, A. \& G. Wall (1982), Tourism: Economic, Physical and Social Impacts, England: Longman Group, UK Ltd.

Mathieson, K. (1991), "Predicting User Intensions: Comparing the Acceptance Model with the Theory Planned Behaviour", Information System Research, 2(3), 173-191.

Mendeleson, N. \& M.J. Polonsky (1995), "Using Strategic Alliances to Develop Credible Green Marketing”, Journal of Consumer Marketing, 12(2), 4-18.

Mengi, Z. (2009), “BB, X, Y ve Z Kuşakları Birbirinden Çok Farklı”, Hürriyet İnsan Kaynakları, (11.10.2009 Pazar), Sayı: 731, s. 8.

Millar, M. \& S. Baloğlu (2008), "Hotel Guests Preferences for Green Hotel”, Hospitality Management, Proceedings of the European Council for Hotel, Restaurant, and Institutional Education Conference, Dubai, United Arab Emirates.

Murray, J. (2008), “Generation Y Demands Greener Employers”, (21.04.2008), Businees Green, <http://www.businessgreen.com/bg/news/1804522/generation-y-demands-greeneremployers>, 24.12.2013. 
Noor, N.A. \& D. Kumar (2014), “Eco Friendly ‘Activities' VS ECO Friendly 'Attitude': Travelers Intention to Choose Green Hotels in Malaysia”, World Applied Sciences Journal, 30(4), 506-513.

Sandahl, D. \& R. Robertson (1989), "Social Determinants of Enviromental Concern; specification and test of the Model", Environment and Behavior, 57-81.

Seçkin, F. (2000), “Türkiye'nin Kuşak Profili”, Capital Dergisi, 12, 100-106.

Straughan, R. \& J. Roberts (1999), "Environmental Segmentation Alternatives: A Look at Green Consumer Behavior in the New Millennium", Journal of Consumer Marketing, 16(6), 558-575.

Van Liere, K.D. \& R.E. Dunalp (1981), “The Social Bases of Environmental Concern: A Review Hypotheses, Explanations and Empirical Evidence”, Public Opinion Quarterly, 44, 181197.

Vining, J. \& A. Ebroe (1990), "What Makes Recycler? A comparision of Recyclers and Nonrecyclers", Environmental Behaviour, 22, 55-73.

Yeşilada, F. (2009), “Kuzey Kıbrıs Türk Cumhuriyeti'nde Çevre Bilinçli Tüketicilerin Profili”, İşletme Fakültesi Dergisi, 10(1), 79-95.

Yüzbaşığlu, S. (2012), “Kuşaklar X,Y,Z diye ayrıştı Pazarlamacıların Kafası Karıştı”, (13.04.2012), Dünya, <http://www.dunya.com/kusaklar-x,-y,-z-diye-ayristi-pazarlamacilarin-kafasikaristi-151507h.htm>, 24.12.2013.

Zeithaml, V. \& L. Berry \& A. Parasuraman (1996), “The Behavioral Consequences of Service Quality", Journal of Marketing, 31-46. 